\title{
Morbidity surveillance and treatment of MDR-TB with the support of NGOs in Ukraine
}

\author{
Inga Pozharova*4, Galyna Daragan ${ }^{1}$, Dmytro Stepanskiy ${ }^{2}$ and Iryna Kolesnikova ${ }^{3}$ \\ 'State Establishment Dnipropetrovsk Medical Academy of the Ministry of Health of Ukraine, Dnipro, Ukraine; ${ }^{2}$ State Establishment \\ Dnipropetrovsk Medical Academy of the Ministry of Health of Ukraine, Dnipro, Ukraine; ${ }^{3}$ Bogomolets National Medical University, \\ Kyiv, Ukraine; ${ }^{4}$ Municipal Healthcare Institution Kramatorsk City Tuberculosis Hospital, Kramatorsk, Ukraine
}

\section{Objective}

Describe the common work of Donetsk State Phthisiological Service and non-governmental organizations that has been conducted since 2014 in order to achieve the global goal for tuberculosis elimination.

\section{Introduction}

The global strategy for eliminating tuberculosis (TB) epidemic "End TB" has been implemented in the world since 2016. Its main goal is to reduce the 2015 TB incidence rate by $90 \%$ and 2015 TB mortality rate by $95 \%$ by 2035 . In Ukraine, in 2016 , the incidence rate of new cases of tuberculosis among the general population was 54.7 per 100 thousand of population (2015 - 55.9), the rate of decrease was $2.1 \pm 0.1 \%$. In Donetsk Oblast (that is under control of Ukrainian authorities), the incidence rate increased by $2.4 \%$ and was 56.4 per 100 thousand of population. The mortality rates were $19 \pm 0.6 \%$ in the country and $29 \pm 2.5 \%$ in Donetsk Oblast. However, according to the World Health Organization (WHO) estimates, we need to enhance the annual incidence rate reduction by $10 \%$ by 2025 , and TB mortality rate should be reduced to $6.5 \%$ in order to achieve the strategy-targeted values.

In Ukraine, as well as globally, there is a crisis of multidrugresistant tuberculosis (MDR-TB). According to WHO estimates, Ukraine belongs to five European countries where 2/3 of MDR-TB cases were registered; the proportion of MDR-TB cases among newly diagnosed TB cases was $16 \%$, and $48 \%$ of repeated cases. In Ukraine, this rate is equal to $24.3 \%$ and $58.2 \%$ in Donetsk Oblast, respectively.

Such results in the Donetsk region may be related to the beginning of hostilities in eastern Ukraine in 2014, which lead to the active migration of population and breakdown of the supply of anti-TB drugs. According to monitoring data, $20 \%$ of with MDR-TB on the territory of the Donetsk region controlled by Ukraine were lost and did not seek medical assistance.

\section{Methods}

This work describes a retrospective cohort study of MDR-TB patients' treatment efficacy. The MDR-TB diagnosis was confirmed by the BSL3 laboratory by molecular genetic testing of sputum using Gene Expert and bacteriological methods to determine resistance to rifampicin and isoniazid.

All MDR-TB patients were divided into 3 cohorts. The first cohort of 86 patients received outpatient treatment within the project "Outpatient Home Treatment Model Using Mobile Response Team" supported by the Foundation for Development of Ukraine in Kramatorsk, Donetsk Oblast, during one year (2014-2015). The response team consisting of a nurse, a driver and a doctor (if necessary) delivered drugs to patients with $\mathrm{TB}$ six times a week. The second cohort of 477 MDR-TB patients has received outpatient treatment via the Red Cross Society since 2015. A nurse visited patients every day and controlled drugs administration. In addition to the treatment, patients were given food kits twice a month. The third cohort of 391 MDR-TB patients received outpatient treatment in healthcare institutions without any support of non-governmental organizations. Before the beginning of the controlled treatment, psychologists worked with patients from risk groups.

\section{Results}

Surveillance data in Donetsk Oblast showed the increase of the MDR-TB morbidity rate from 15.0 to 20.1 per 100 thousand of population. According to the analysis results, MDR-TB is found in $31 \%$ of cases among all newly diagnosed TB cases.

The successful treatment rate of all TB cases in Donetsk Oblast in 2015 was $61.9 \pm 5.4 \%$, which is lower than the average rate in Ukraine, which is $11.1 \pm 1.0 \%$ (WHO indicator is $75 \%$ ). The number of MDR-TB cases with "treatment failure" (treatment was completed, but bacterial secretion continued) $-9.3 \pm 2.6 \%$ and "interrupted treatment" $-13.3 \pm 2,6 \%$ is very high in Donetsk Oblast.

Results analysis of the controlled treatment showed that the treatment efficacy for MDR-TB patients in the first cohort was $75 \%$. In the second cohort, 205 out of 477 patients completed their treatment. The treatment efficacy was $78.5 \%$. In the third cohort $45.0 \%$ of patients were cured, which corresponds to general rates in this oblast. However, the treatment efficacy for MDR-TB patients, who received the support of non-governmental organizations, was $30,0-33.5 \%$ higher than among patients who did not receive such support (Table 1)

\section{Conclusions}

The cooperation of the State Phthisiatrician Service with nongovernmental organizations concerning patients at the outpatient stage of treatment and development of treatment adherence increased the treatment efficacy for MDR-TB patients by almost $30 \%$, which is important to control the spread of dangerous sources of tuberculosis agents in order to improve the epidemic situation.

Cohort analysis of treatment results and clinical MDR-TB monitoring reflects the peculiarities of the epidemic situation and reveals errors in the work of the State Phthisiatrician Service in Donetsk Oblast. Nevertheless, the results show that common work of healthcare institutions, non-governmental organizations and volunteers can bring significant results in strengthening TB patients care.

Table 1. Treatment results of MDR-TB patients (2014-2016)

\begin{tabular}{|c|c|c|c|c|c|c|}
\hline \multirow{2}{*}{} & \multicolumn{2}{|c|}{$\begin{array}{c}\text { Treatment Using Mobile Response } \\
\text { Team (Cohort 1) }\end{array}$} & \multicolumn{2}{|c|}{$\begin{array}{c}\text { Treatment via Red Cross } \\
\text { Society(Cohort 2) }\end{array}$} & \multicolumn{2}{|c|}{$\begin{array}{c}\text { Directly Observed Treatment in } \\
\text { Healthcare Institutions } \\
\text { (Cohort 3) }\end{array}$} \\
\cline { 2 - 7 } & Absolute number & $\%$ & Absolute number & $\%$ & Absolute number & $\%$ \\
\hline Cured & 64 & $75 \%$ & 161 & $78,5 \%$ & 175 & $45 \%$ \\
\hline $\begin{array}{c}\text { Treatment } \\
\text { Failure }\end{array}$ & 6 & $7 \%$ & 15 & $7,3 \%$ & 44 & $11 \%$ \\
\hline Died & 2 & $2,3 \%$ & 5 & $2,4 \%$ & 54 & $14 \%$ \\
\hline $\begin{array}{c}\text { Interrupted } \\
\text { Treatment }\end{array}$ & 0 & 0 & 4 & $2,0 \%$ & 71 & $18 \%$ \\
\hline $\begin{array}{c}\text { Moved out the } \\
\text { oblast }\end{array}$ & 14 & $15,7 \%$ & 20 & $9,8 \%$ & 47 & $12 \%$ \\
\hline Total & 86 & $100 \%$ & 205 & $100 \%$ & 391 & $100 \%$ \\
\hline
\end{tabular}

Keywords

surveillance; tuberculosis; non-goverment organization

*Inga Pozharova

E-mail: ingapozharova@gmail.com 